\title{
Forest composition, fuel loading, and soil chemistry resulting from 50 years of forest management and natural disturbance in two southeastern Coastal Plain watersheds, USA
}

\author{
T. Adam Coates ${ }^{\mathrm{a}, *}$, Andrew Johnson ${ }^{\mathrm{a}}$, W. Michael Aust ${ }^{\mathrm{a}}$, Donald L. Hagan ${ }^{\mathrm{b}}$, Alex T. Chow ${ }^{\mathrm{b}, \mathrm{c}}$, \\ Carl Trettin ${ }^{\mathrm{d}}$ \\ ${ }^{a}$ Department of Forest Resources and Environmental Conservation, Virginia Polytechnic Institute and State University, Blacksburg, VA 24061, USA \\ ${ }^{\mathrm{b}}$ Department of Forestry and Environmental Conservation, Clemson University, Clemson, SC 29634, USA \\ ${ }^{\mathrm{c}}$ Baruch Institute of Coastal Ecology and Forest Science, Clemson University, Georgetown, SC 29440, USA \\ ${ }^{\mathrm{d}}$ USDA Forest Service Southern Research Station, Cordesville, SC, 29434, USA
}

\section{A R T I C L E I N F O}

\section{Keywords:}

Prescribed fire

Thinning

Salvage logging

Hurricane Hugo

Silviculture

Litter

Duff

Carbon

Nitrogen

Calcium

Phosphorus

Woody debris

\begin{abstract}
A B S T R A C T
Globally, prescribed fire, harvesting, and understory mastication, alone and in combination, are common forest management practices. Timber commodities, wildlife habitat, wildfire fuel reduction, soil conservation, and water quality are frequently targeted and assessed as these practices are utilized. In the 1960s, a study of paired, first-order watersheds was established in coastal South Carolina, USA, to evaluate the long-term impacts of forest management (i.e. prescribed fire, thinning, mastication of understory vegetation) on water quantity and quality. Following Hurricane Hugo in 1989, this included salvage logging on one watershed, but not the other. In 2015, these watersheds were comprehensively evaluated to determine differences in forest species composition, fuels, and soil chemistry. Softwood basal area was greater in the managed watershed than in the unmanaged watershed and hardwood basal area was greater in the unmanaged watershed than in the managed watershed. Total fuel mass did not differ between the two watersheds, but 1-hr and 1000-hr rotten fuel mass were greater on the unmanaged watershed. Ten-hr fuel mass was greater on the managed watershed. Calcium, nitrogen, magnesium, phosphorus, potassium, and pH differed between the litter (Oi horizon) and duff (Oe + Oa horizons) of both watersheds, but carbon only differed in the duff. Mineral soil (Ultisols, 0-10 and 10-20 cm depths) calcium and phosphorus differed between the watersheds, but $\mathrm{pH}$ and the other chemicals did not. Collectively, these results indicated that: (1) forest management and natural disturbance on these watersheds altered long-term forest structure; (2) different species compositions and the inclusion or exclusion of salvage logging after Hurricane Hugo produced different fuel compositions that may potentially impact potential wildfire hazard and fire behavior; (3) organisms as a primary soil-forming factor were impacted by long-term management, therefore, some soil chemical properties were affected. Collectively, these analyses highlighted the broad, long-term impacts to ecosystem properties and processes that might directly and indirectly result from active forest management and natural disturbance and the scale of site-specific assessment that might be considered when landowner objectives are targeted in forest management plans and practices.
\end{abstract}

\section{Introduction}

Globally, forests cover approximately 4 million ha, accounting for approximately $30 \%$ of earth's land surface. As of $2010,53 \%$ of forests had an existing and active forest management plan (Keenan et al., 2015). Such management plans, with specific management techniques, are often implemented to attain specific owner or agency objectives, such as production of timber and wood commodities or wildlife habitat (Waldrop and Goodrick, 2012). Globally, prescribed fire and harvesting are two techniques commonly used in forest management (Johnson and Curtis, 2001). Understanding spatial and temporal impacts that these practices induce on ecosystem properties and processes, such as influencing potentially hazardous wildland fuels, soil properties, and water quality, is an essential part of forest management planning (Oliver and

\footnotetext{
Abbreviations: Ca, calcium; C, carbon; Mg, magnesium; N, nitrogen; P, phosphorus; K, potassium; SEF, Santee Experimental Forest; DBP, disinfection by-product

* Corresponding author at: 228F Cheatham Hall, 310 West Campus Dr., Blacksburg, VA 24061, USA.

E-mail address: acoates4@vt.edu (T.A. Coates).
} 
Larson, 1996; Johnson and Curtis, 2001).

Potentially hazardous wildland fuels are an international concern (Flannigan et al., 2013; Keane, 2013; Williams, 2013; Schwilk et al., 2009). Recent wildfire events in the Amazon, Australia, and the United States have highlighted some significant dynamics, such as larger fire events generating higher suppression costs occurring during extended fire seasons in areas more heavily influenced by human development (Abatzoglou and Williams, 2016). In many locations, concerns are escalated by current climate projections through the year 2100 (Collins and Knutti, 2013).

Active forest management, which includes implementation of intensive silvicultural practices, may alter the amount and composition of potentially hazardous wildland fuels (Vander Yacht et al., 2019; Waldrop et al., 2016; Schwilk et al., 2009). Dominant vegetative types change over time through ecological succession in the presence or absence of natural and anthropogenic disturbances (Gilliam and Platt, 1999). Active forest management that favors one successional state over another or one specific vegetative composition may, in turn, affect both the total amount and type of fuel available to burn when and if a wildfire ignition occurs (Tiribelli et al., 2019; Uyehara and Pacala, 2018; Waldrop and Goodrick, 2012).

Worldwide, soil conservation also continues to be a major topic of concern. Soils serve as a medium for biological productivity (Alcaniz et al., 2018; Page-Dumroese et al., 2010). As much as soils influence potential vegetation, vegetation also influences soil resources as one of the primary soil-forming factors (Jenny, 1941). Therefore, as was stated previously regarding fuels, as vegetation changes over time through the natural process of ecological succession, soil physical, biological, and chemical properties may also change. Potential alterations in soil calcium $(\mathrm{Ca})$, carbon $(\mathrm{C})$, nitrogen $(\mathrm{N})$, magnesium $(\mathrm{Mg})$ phosphorus $(\mathrm{P})$, potassium (K), or $\mathrm{pH}$ may be noted as a result of active forest management in a given soil type (Hume et al., 2016; Li et al., 2013; Lynham et al., 1998).

Numerous forests of the southeastern Coastal Plain, USA, are actively managed today through the use of prescribed burning practices, alone or in combination, and provide evidence of potential ecosystem impacts resulting from active forest management (Melvin, 2018; Mitchell and Duncan, 2009). Significant forest fuel composition and load changes may occur in longleaf pine (Pinus palustris Mill.) dominated forests if fire return intervals are extended beyond three years (Glitzenstein et al., 1993), for example. In the absence of frequent prescribed fire, understory vegetation may rapidly shift from a wiregrass (Aristida stricta Michx.) dominated composition to one dominated by woody stems (Noss, 2018). It has been noted that longleaf pinewiregrass fuel cells maintained with frequent fire may vary spatially across the landscape at a scale of $0.25 \mathrm{~m}^{2}$ (Loudermilk et al., 2017; Hiers et al., 2009). At this scale, fire behavior, and any subsequent fire effects, may be impacted by the intricacy of fuel pattern and orientation, not to mention other fire environment variables (i.e. fire weather, microtopography, etc.). This fine-scale fuel complexity characterizes frequent fire landscapes and points toward additional fuel complexities that might be identified for fire excluded or infrequent fire landscapes. Therefore, fuel assessments are a critical consideration of active forest management.

Silvicultural impacts to southeastern soils have been quite varied as a result of the soil type impacted, the soil property measured and the time of that measurement (both seasonally and post-harvest), the type of mechanized equipment used (if any), and the extent of biomass removed (Coates, 2006; Johnson and Curtis, 2001). Fox et al. (2007) summarized typical pine plantation management in the southeastern United States as involving mechanical, chemical, and prescribed burning site preparation, planting improved seedlings, competition control, fertilization, thinning, and final harvest. Aust et al. (2019) described current silvicultural manipulations for wetter sites in the southeastern Coastal Plain as involving both planted pine and naturally regenerated hardwoods and a variety of harvesting equipment that is intended to minimize soil impacts. Silvicultural manipulations can clearly affect forest soils in numerous and complex ways.

Soils-related prescribed fire effects have been measured in the southeastern Coastal Plain and the results vary based upon multiple factors such as soil type, chemical property in question, fire regime investigated (i.e. fire frequency, season of burn, fuels, climate), fire weather (related to specific burn days), time of sampling and sampling technique, and laboratory techniques utilized (Coates et al., 2018; Fairchilds and Trettin, 2006; McKee, 1982). In four studies of Coastal Plain pine forests situated on clay-dominated Ultisols, total nitrogen $(\mathrm{N})$ was not significantly affected as a result of long-term prescribed fire use when measured at the $0-16 \mathrm{~cm}$ depth in South Carolina and Alabama (McKee, 1982), 0-20 cm depth in South Carolina (Binkley et al., 1992), and $0-10 \mathrm{~cm}$ depth in Florida (Godwin et al., 2017). Site preparation prescribed fire also induced no soil $\mathrm{N}$ changes at the $0-15 \mathrm{~cm}$ depth in Georgia (Boyer and Miller, 1994). Godwin et al. (2017) noted nonsignificant increases in phosphorus (P), calcium (Ca), potassium (K), and $\mathrm{pH}$ as a result of burning, but carbon (C) and magnesium (Mg) increased significantly. McKee (1982) observed significantly increased $\mathrm{P}$ and $\mathrm{Ca}$ at the $0-5 \mathrm{~cm}$ (Alabama) and 0-8 cm depths (South Carolina) as a result of prescribed burning. This author suggested that a lack of fire might lead to $\mathrm{Ca}$ immobilization in the O horizon, subsequently impacting early successional vegetation, biological richness, and species diversity. Soil results indicating increases and non-significant effects of prescribed fire stand in contrast to broad syntheses of soil-related wildland fire effects highlighted by Pellegrini et al. (2017) and Carter and Foster (2004). Both authors suggested that increased fire frequency may compromise soil productivity and fertility long-term by reducing soil $\mathrm{C}$ and $\mathrm{N}$.

In Coastal Plain South Carolina (USA), a unique study was established in the 1960s to determine the long-term implications of active forest management on ecosystem properties and processes in two paired watersheds (Amatya and Trettin, 2007; Harder et al., 2006). One watershed has been managed over the last 50 years and the other has not. Both watersheds were heavily impacted by Hurricane Hugo in 1989. Recently, Majidzadeh et al. (2019) observed that water quality was enhanced on the managed watershed as a result of the long-term inclusion of active management practices. In this paper, we would like to address potential long-term changes in forest composition, forest fuel loading, and soil chemical properties within these watersheds.

Our hypotheses were:

a. Forest composition has been altered by natural disturbance and forest management (i.e. hardwood composition is greater on the unmanaged watershed as a result of ecological succession and softwood composition is greater on the managed watershed because silvicultural treatments have promoted softwood dominance)

b. Forest floor and fuel physical properties have been altered by natural disturbance and forest management (i.e. total fuel loading is greater on the unmanaged watershed than on the managed watershed, largely as a result of greater 1000-hr fuels on the unmanaged watershed that remain following Hurricane Hugo)

c. Forest floor and mineral soil chemistry have been altered by natural disturbance and forest management (i.e. C, N, Ca, Mg, K, P, pH have been affected by the long-term changes in overstory tree species dominance between watersheds)

\section{Materials and methods}

\subsection{Study site (Fig. 1 Map, Fig. 2 Photos) (Table 1 disturbance/ management history)}

Two paired, experimental, coastal, first-order watersheds within the Santee Experimental Forest of the Francis Marion National Forest in Cordesville, South Carolina (USA) were utilized for this study (Fig. 1). Lands comprising this forest have been used for agriculture and forestry 


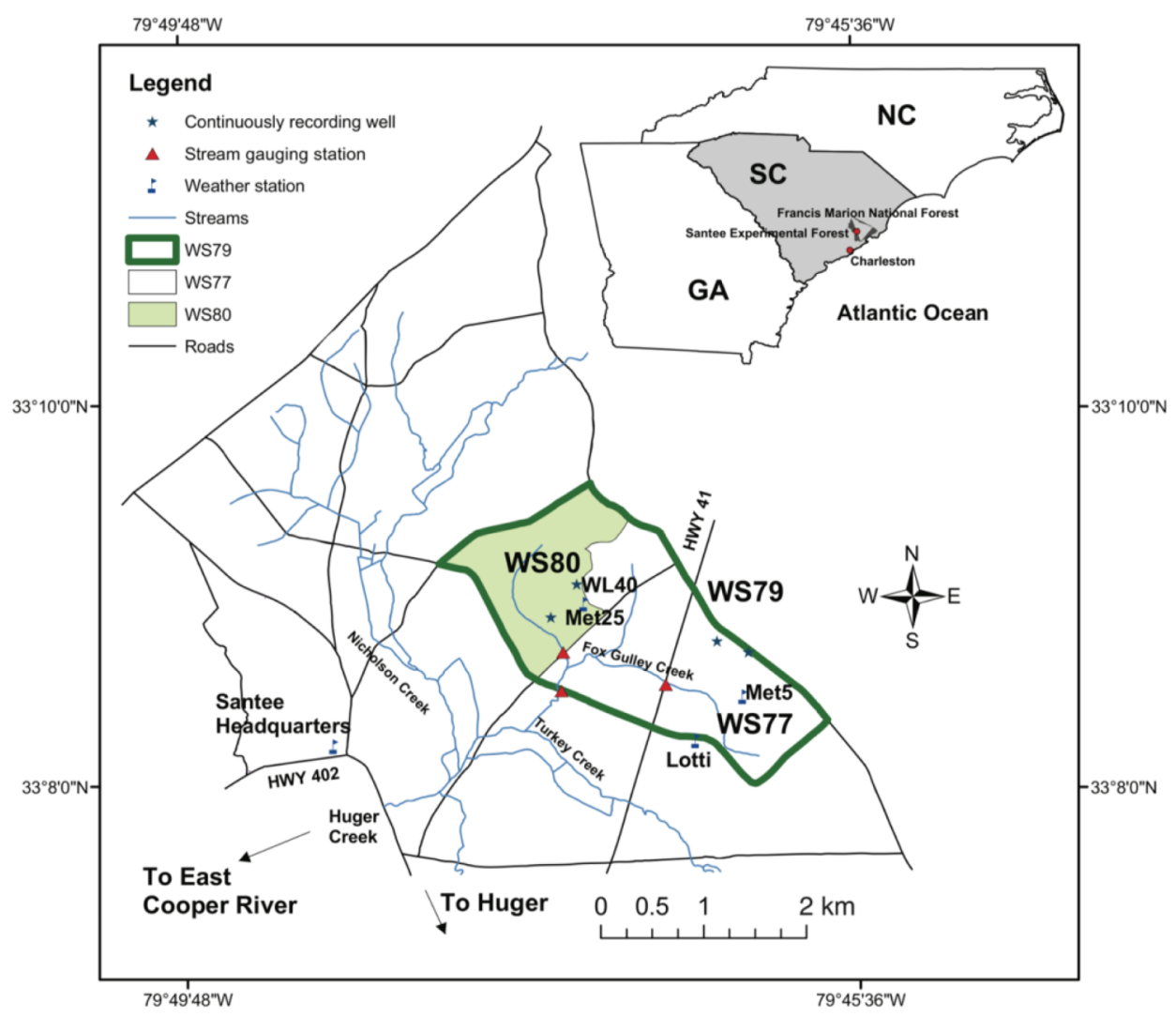

Fig. 1. Location of the experimental watersheds (Watersheds 77-managed and 80-unmanaged) utilized for this study on the USDA Forest Service Southern Research Station's Santee Experimental Forest, Cordesville, South Carolina (Majidzadeh et al., 2019; Harder et al., 2006).

since the early 1700s (Dai et al., 2013). The unmanaged watershed, Watershed 80 , is a 160 -ha watershed that has not been subjected to forest management practices since 1968 and serves as a control site for the USDA Forest Service Southern Research Station Center for Forested Wetlands Research (Amatya and Trettin, 2007). The managed watershed, Watershed 77, is a 160-ha watershed that has been actively managed since 1963 with a host of silvicultural practices including prescribed fire, thinning, and mastication (i.e. mowing of understory vegetation) (Table 1) (Amatya et al., 2006; Harder et al., 2006). One large, natural disturbance of note affecting both watersheds equally in 1989 was Hurricane Hugo; approximately $80 \%$ of the dominant trees in both watersheds were broken or uprooted (Hook et al., 1991). No posthurricane debris was removed from the unmanaged watershed and no silvicultural practices were utilized for stand recovery. The managed watershed has been burned every 2-4 years since 2003 . Representative photographs of both watersheds were taken in 2015 and are shown in Fig. 2.

The dominant trees on both watersheds were loblolly pine (Pinus taeda L.), longleaf pine (Pinus palustris Mill.), red maple (Acer rubrum L.), sweetgum (Liquidambar syraciflua L.), and many oaks (Quercus spp.). The soils have developed in marine sediments and have drainage varying from very poorly drained in the riparian zones to moderately well drained in the uplands. They are defined as aquic Alfisols or Ultisols, containing argillic horizons (Jayakaran et al., 2014). For the purposes of this study, we confined our soil sampling locations to Ultisols-only and the following soil series designations: Wahee, Coxville, Eulonia, and Goldsboro. Sampling location elevation on both watersheds was $5.0 \mathrm{~m}$ to $21.6 \mathrm{~m}$.

\subsection{Sampling}

\subsubsection{Overstory composition}

A randomized sampling grid was established for each watershed in
January 2015. Thirty-six total locations were sampled: 20 on the managed watershed and 16 on the unmanaged watershed. Sampling locations within each watershed were approximately $300 \mathrm{~m}$ apart. At each sampling location, a 0.02 ha $(13.4 \mathrm{~m} \times 15.2 \mathrm{~m})$ fixed area plot was established to determine overstory composition and basal area (Fig. 3). Trees $>5 \mathrm{~cm}$ diameter at breast height (DBH) and $2 \mathrm{~m}$ tall were tallied by $5-\mathrm{cm}$ DBH classes and species. Basic categories of hardwood and softwood for each tree species were utilized to determine differences in stand composition.

\subsubsection{Woody debris and forest floor physical properties}

Within the 0.02 ha fixed area plot, Brown's Planar Intercept Method (Brown, 1974) was utilized to determine coarse woody debris mass and forest floor depth. Using this method, as modified by Coates et al. (2019) and Stottlemyer (2004), three $15.2 \mathrm{~m}$ transects were oriented at a $45^{\circ}$ angle along the forest floor surface to tally individual woody debris particles and generate woody debris mass by diameter and timelag fuel-size class: $0-0.64 \mathrm{~cm}$ (1-hr), $0.65-2.54 \mathrm{~cm}$ (10-hr), $2.55-7.62 \mathrm{~cm}$ (100-hr), $>7.62 \mathrm{~cm}$ (1000-hr) (Fig. 3). Timelag refers to how an individual fuel-size class responds to changes in relative humidity (Brown, 1974). Using this method, 1-hr and 10-hr fuels were tallied within the first $1.83 \mathrm{~m}$ of each transect, 100 -hr fuels were tallied within the first $3.66 \mathrm{~m}$, and 1000-hr fuels were tallied along the entire $15.2 \mathrm{~m}$ transect. A quality rating (sound or rotten) was additionally recorded for 1000-hr fuels based upon exterior physical properties (Lutes and Keane, 2006; Maser et al., 1979). If any portion of a 1000-hr fuel's texture appeared soft when kicked, for example, that fuel was classified as rotten.

Estimates of fuel loading in tons acre ${ }^{-1}(\mathrm{~W})$ were derived for each fuel-size class based upon these equations (Brown, 1974) and converted to $\mathrm{Mg} \mathrm{ha}^{-1}$ :

For material with diameter $\leqslant 7.62 \mathrm{~cm} \mathrm{~W}=2.24\left[(11.64)\left(\mathrm{n} * \mathrm{~d}^{2} * \mathrm{~s} * \mathrm{a} * \mathrm{c}\right) / \mathrm{N} * \mathrm{~L}\right]$ 

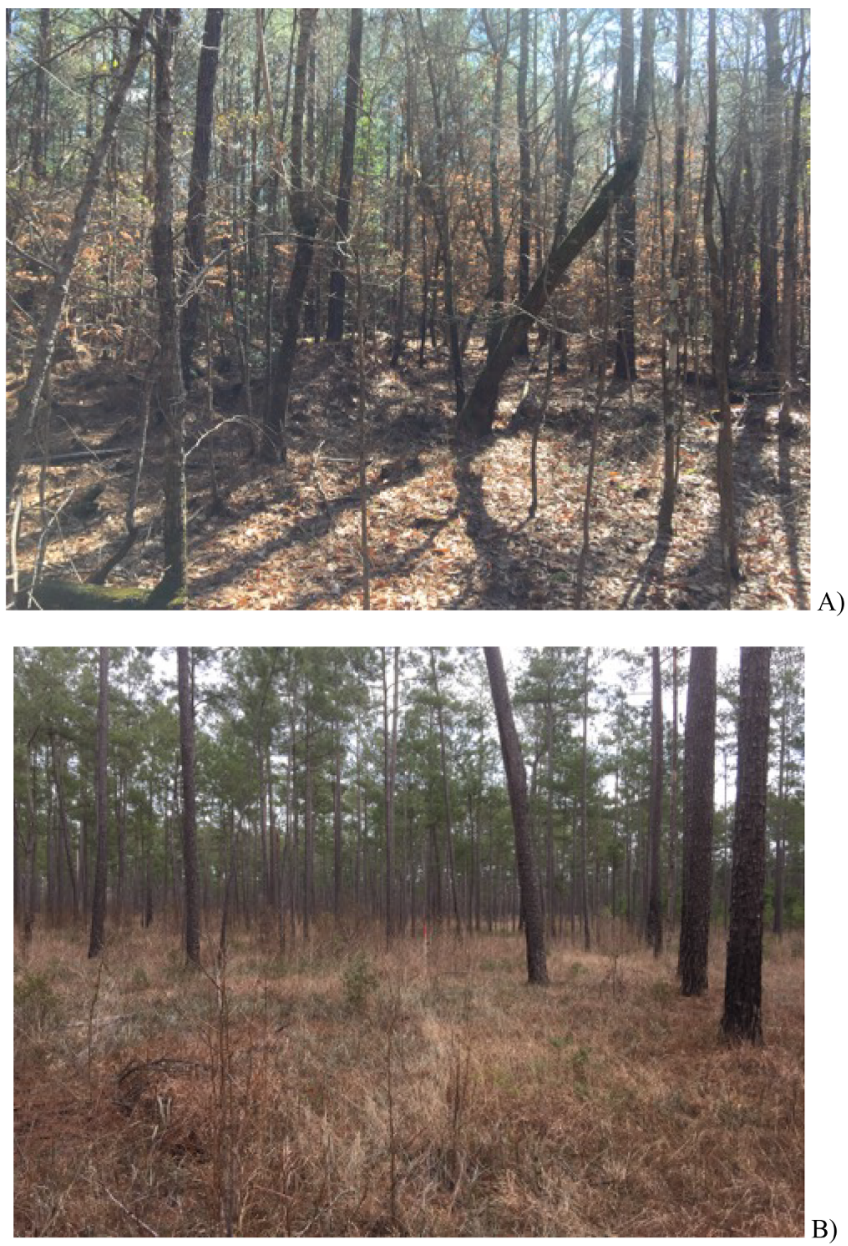

Fig. 2. Images from sites at the (A) unmanaged and (B) managed watersheds, Santee Experimental Forest, Cordesville, South Carolina, USA.

Table 1

Chronology of forest management practices and natural disturbances on both the managed (Watershed 77) and unmanaged watersheds (Watershed 80) of the Santee Experimental Forest, Cordesville, South Carolina, USA (dates added to Amatya et al., 2006).

\begin{tabular}{ll}
\hline Year (s) & Description of treatments/disturbances \\
\hline 1963 & Watershed 77 established as a managed, treatment watershed \\
1968 & Watershed 80 established as a control, unmanaged watershed \\
$1977-1981$ & $\begin{array}{l}\text { 100\% of Watershed 77 is prescribed burned at various times over a } \\
5 \text { year period }\end{array}$ \\
1989 & Hurricane Hugo damages 80\% of forests on both watersheds (Sept.) \\
1990 & Watershed 77 is salvage-harvested (entire vegetation harvested and \\
& removed) \\
& Watershed 80 is left untouched \\
2001 & Mastication of understory vegetation occurred on portions of \\
2003 & Watershed 77 (Feb.-Nov.) \\
2006 & Watershed 77 prescribed burned on May 10 \\
2007 & Watershed 77 whole-tree thinning of understory in early July \\
2009 & Watershed 77 prescribed burned on June 7 \\
2013 & Watershed 77 prescribed burned on April 21 \\
\hline
\end{tabular}

For material with diameter $>7.62 \mathrm{~cm}: \mathrm{W}=2.24\left[(11.64)\left(\sum \mathrm{d}^{2} * \mathrm{~s} * \mathrm{a} * \mathrm{c}\right) / \mathrm{N} * \mathrm{~L}\right]$

where

$2.24=$ conversion factor of tons acre ${ }^{-1}$ to $\mathrm{Mg} \mathrm{ha}^{-1}$

$11.64=$ conversion factor of volume to tons acre ${ }^{-1}$
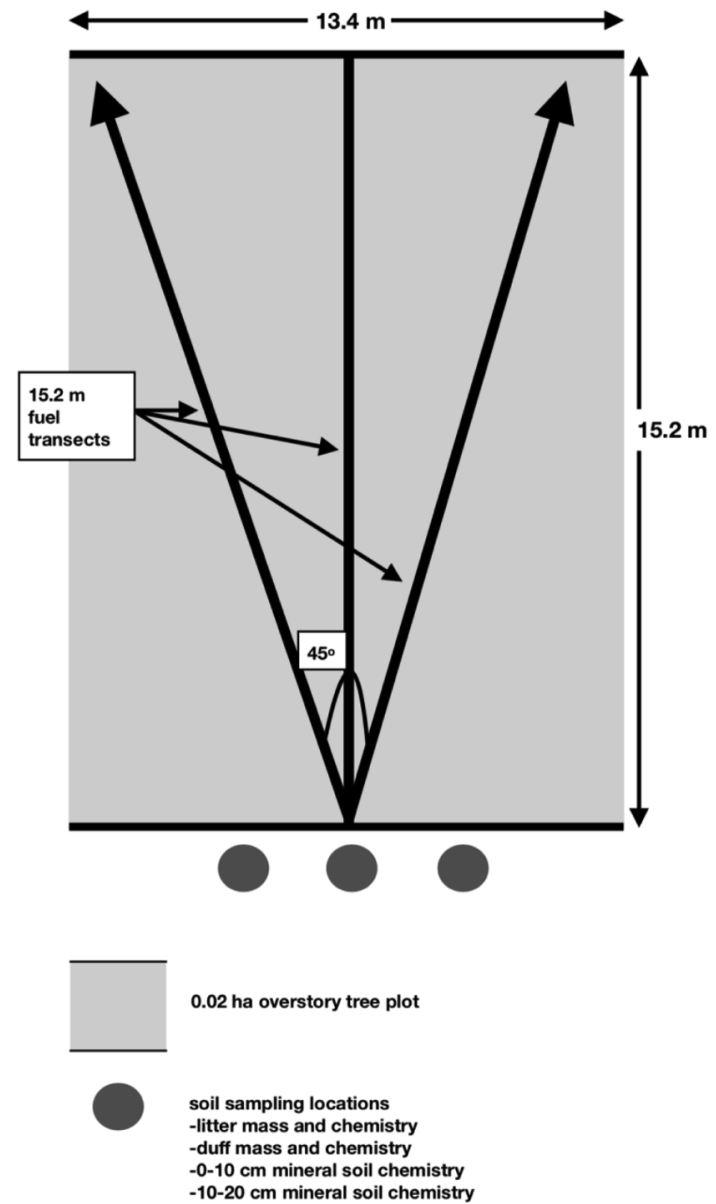

Fig. 3. Plot layout for each sampling location (located approximately $300 \mathrm{~m}$ apart) utilized to determine overstory composition, forest floor physical and chemical properties, and mineral soil chemical properties on the unmanaged and managed watersheds of the Santee Experimental Forest, Cordesville, South Carolina, USA.

$\mathrm{n}=$ the number of woody fuels tallied per timelag-size class

$\mathrm{d}=$ quadratic-mean-diameter of particles (in)

$\mathrm{s}=$ specific gravity of fuels $(\mathrm{s}=0.70,0.58,0.58$, and 0.30 for 1 and 10-hr, 100-hr, 1000-hr sound, and 1000-hr rotten material, respectively) (Anderson, 1982)

$\mathrm{a}=$ non-horizontal angle factor correction factor

$\mathrm{c}=$ slope correction factor

$\mathrm{N}=$ number of transects at each plot $(\mathrm{N}=3)$

$\mathrm{L}=$ length $(\mathrm{ft})$ of sampling plane $(\mathrm{L}=6$ for 1 - and 10-hr fuels;

$\mathrm{L}=12$ for 100 -hr fuels; and $\mathrm{L}=50$ for 1000 -hr fuels)

Litter depth (cm), duff depth (cm) (when present), and fuel bed height $(\mathrm{cm}$; defined as the distance from the top of the litter layer to the top of any coarse woody debris crossing the transect) were measured at three locations along each $15.2 \mathrm{~m}$ transect: $3.7-4.0 \mathrm{~m}, 7.3-7.6 \mathrm{~m}$, and 12.2-12.5 m. Therefore, plot averages for each variable were based upon nine individual measurements (three measurements taken along each of the three transects within each plot). Litter and duff masses were derived using samples described in Section 2.2.3.

\subsubsection{Forest floor and mineral soil chemistry}

Approximately 1-2 m outside the lower boundary of each 0.02 ha fixed area plot, three forest floor and mineral soil sampling locations were established approximately $1 \mathrm{~m}$ apart (Fig. 3). Litter (Oi horizon; including any down-and-dead understory vegetation) and duff (Oe + Oa horizons) materials (when present) were destructively 
sampled using a $0.3 \mathrm{~m} \times 0.3 \mathrm{~m}$ frame. These samples were taken to the laboratory, oven-dried at $65{ }^{\circ} \mathrm{C}$ for no less than $48 \mathrm{hrs}$, and weighed to determine the oven-dry mass of each sample. After drying, the three samples obtained at each location were composited to create one sample each of both litter and duff per sampling location. These samples were then ground using a Wiley mill $(2 \mathrm{~mm})$.

Mineral soil samples were obtained directly underneath the removed forest floor materials to the $0-10$ and $10-20 \mathrm{~cm}$ soil depths using an Oakfield Model H soil probe (Oakfield Apparatus, Fond du Lac, WI, USA; inner diameter $2.06 \mathrm{~cm}$ ). In the field, these samples were composited to create one sample for each depth per plot. These samples were also taken to the laboratory and any rock and root fragments were removed. The samples were then oven-dried at $65^{\circ} \mathrm{C}$ for no less than 48 hrs and hand-sieved to $2 \mathrm{~mm}$.

\subsubsection{Laboratory analyses}

Laboratory analyses were contracted to Brookside Laboratories in New Bremen, OH, USA and approximately $30 \mathrm{~g}$ of litter, duff, and mineral soil (0-10 and 10-20 cm soil depths) were utilized to determine concentrations of the following chemical properties: C, Ca, Mg, N, P, K, and soil $\mathrm{pH}$. Carbon and $\mathrm{N}$ were determined by the combustion of samples and subsequent measurements conducted with the PerkinElmer 2400 Series CHNS/O Analyzer (Nelson and Sommers, 1996). The additional element concentrations were determined using Mehlich III methodology (Mehlich, 1984) and subsequent analysis for each element of interest by ICP-Optical Emission Spectrometry (Boss and Fredeen, 2004). Soil pH was determined using a 1:1 soil to water solution (McLean, 1982).

\subsection{Statistical analyses}

All statistical analyses were conducted using $\mathrm{JMP}^{\circledR}$ (Version 14, SAS Institute Inc., Cary, NC, USA). Differences in watershed basal area; woody debris mass; litter mass, depth, and chemistry; duff mass, depth, and chemistry; fuelbed height; and mineral soil chemistry were determined using Wilcoxon t-tests for nonparametric datasets. Differences were declared statistically significant at $\alpha=0.05$.

\section{Results}

\subsection{Overstory composition)}

Mean total basal area was greater on the unmanaged watershed (45.6 $\left.\mathrm{m}^{2} \mathrm{ha}^{-1}\right)$ than on the managed watershed $\left(34.5 \mathrm{~m}^{2} \mathrm{ha}^{-1}\right)$ (p $<0.01$ ) (Table 2). Further analyses by broad species categories suggested that mean softwood basal area was greater on the managed watershed $\left(27.1 \mathrm{~m}^{2} \mathrm{ha}^{-1}\right)$ than on the unmanaged watershed $\left(19.0 \mathrm{~m}^{2}\right.$ $\left.\mathrm{ha}^{-1}\right)(\mathrm{p}<0.01)$ and mean hardwood basal area was greater on the unmanaged watershed $\left(26.6 \mathrm{~m}^{2} \mathrm{ha}^{-1}\right)$ than on the managed watershed $\left(7.4 \mathrm{~m}^{2} \mathrm{ha}^{-1}\right)(\mathrm{p}=0.02)$.

\subsection{Forest floor and fuel physical properties}

Mean total forest floor depth (Oi $+\mathrm{Oe}+\mathrm{Oa}$ ) was greater on the unmanaged watershed $(6.3 \mathrm{~cm})$ than the managed watershed $(5.4 \mathrm{~cm})$ $(p=0.04$ ) (Table 2). Mean litter depth was 4.6 and $4.9 \mathrm{~cm}$ for the unmanaged and managed watersheds, respectively, and did not differ statistically ( $\mathrm{p}=0.82$ ). Duff depth was 1.7 and $0.4 \mathrm{~cm}$ for the unmanaged and managed watersheds, respectively, and did differ statistically ( $\mathrm{p}<0.01$ ). Mean fuel bed depth was greater on the unmanaged watershed $(7.8 \mathrm{~cm})$ than the managed watershed $(3.2 \mathrm{~cm})(\mathrm{p}<0.01)$.

Mean total fuel mass (forest floor mass + coarse woody debris mass) was 51.4 and $46.7 \mathrm{Mg} \mathrm{ha}^{-1}$ for the unmanaged and managed watersheds, respectively, and did not differ significantly $(\mathrm{p}=0.45)$ (Table 2). Mean total forest floor mass (Oi $+\mathrm{Oe}+\mathrm{Oa})$ was $25.0 \mathrm{Mg} \mathrm{ha}{ }^{-1}$ and $21.5 \mathrm{Mg} \mathrm{ha}^{-1}$ for the unmanaged and managed
Table 2

Basal area $\left(\mathrm{m}^{2} \mathrm{ha}^{-1}\right)$, fuel mass $\left(\mathrm{Mg} \mathrm{ha}^{-1}\right)$, and fuel depth $(\mathrm{cm})$ parameters measured on the Santee Experimental Forest unmanaged and managed watersheds, Cordesville, SC, USA ( $\alpha=0.05)$.

\begin{tabular}{|c|c|c|c|c|}
\hline Property & $\begin{array}{l}\text { Unmanaged } \\
(\mathrm{n}=16)\end{array}$ & $\begin{array}{l}\text { Managed } \\
(\mathrm{n}=20)\end{array}$ & $\begin{array}{l}\text { Z-test } \\
\text { Statistic }\end{array}$ & p-value \\
\hline \multicolumn{5}{|c|}{ Composition $\left(\mathrm{m}^{2} \mathrm{ha}-{ }^{1}\right)$} \\
\hline Total Basal Area & $45.6 \pm 1.8$ & $34.5 \pm 2.2$ & 3.26 & $<0.01$ \\
\hline $\begin{array}{l}\text { Hardwood Basal } \\
\quad \text { Area }\end{array}$ & $26.6 \pm 2.4$ & $7.4 \pm 1.7$ & -2.23 & 0.02 \\
\hline $\begin{array}{l}\text { Softwood Basal } \\
\text { Area }\end{array}$ & $19.0 \pm 2.7$ & $27.1 \pm 1.7$ & 4.47 & $<0.01$ \\
\hline \multicolumn{5}{|c|}{ Fuel Mass ( $\left.\mathrm{Mg} \mathrm{ha}^{-1}\right)$} \\
\hline Total Fuel Mass & $51.4 \pm 5.0$ & $46.7 \pm 4.6$ & 0.75 & 0.45 \\
\hline Forest Floor Mass & $25.0 \pm 1.8$ & $21.5 \pm 2.5$ & 1.29 & 0.19 \\
\hline Litter Mass & $12.5 \pm 0.9$ & $12.5 \pm 1.1$ & 0.05 & 0.95 \\
\hline Duff Mass & $12.5 \pm 1.4$ & $9.0 \pm 2.3$ & 2.23 & 0.03 \\
\hline $\begin{array}{l}\text { Down-and-Dead } \\
\text { Woody Debris } \\
\text { Mass }\end{array}$ & $26.4 \pm 4.1$ & $25.2 \pm 4.3$ & 0.65 & 0.51 \\
\hline 1-Hr Fuel & $0.6 \pm 0.1$ & $0.2 \pm 0.1$ & 4.03 & $<0.01$ \\
\hline 10-Hr Fuel & $3.6 \pm 0.4$ & $5.0 \pm 0.5$ & -2.03 & 0.04 \\
\hline 100-Hr Fuel & $4.3 \pm 0.8$ & $5.8 \pm 0.8$ & -1.48 & 0.14 \\
\hline 1000-Hr Fuel & $17.9 \pm 3.2$ & $14.1 \pm 4.1$ & 1.70 & 0.09 \\
\hline 1000-Hr Rotten & $16.8 \pm 3.0$ & $10.5 \pm 3.6$ & 2.26 & 0.02 \\
\hline 1000-Hr Sound & $1.2 \pm 0.5$ & $3.6 \pm 2.1$ & -0.61 & 0.55 \\
\hline \multicolumn{5}{|l|}{ Fuel Depth (cm) } \\
\hline Forest Floor Depth & $6.3 \pm 0.6$ & $5.4 \pm 0.3$ & 2.01 & 0.04 \\
\hline Litter Depth & $4.6 \pm 0.4$ & $4.9 \pm 0.3$ & -0.22 & 0.82 \\
\hline Duff Depth & $1.7 \pm 0.1$ & $0.4 \pm 0.2$ & 3.83 & $<0.01$ \\
\hline Fuel Bed Height & $7.8 \pm 0.8$ & $3.2 \pm 0.3$ & 4.17 & $<0.01$ \\
\hline
\end{tabular}

watersheds, respectively, and was not significantly different between the watersheds $(\mathrm{p}=0.19)$. Mean litter mass followed this trend with $12.5 \mathrm{Mg} \mathrm{ha}^{-1}$ on both watersheds $(\mathrm{p}=0.95)$. Mean duff mass differed, however, with $12.5 \mathrm{Mg} \mathrm{ha}{ }^{-1}$ on the unmanaged watershed and 9.0 $\mathrm{Mg} \mathrm{ha}{ }^{-1}$ on the managed watershed $(\mathrm{p}=0.03)$.

Mean coarse woody debris mass (1-hr $+10-\mathrm{hr}+100-\mathrm{hr}+1000-\mathrm{hr}$ fuels) did not differ by watershed ( $\mathrm{p}=0.51$ ), with $26.4 \mathrm{Mg} \mathrm{ha}^{-1}$ and $25.2 \mathrm{Mg} \mathrm{ha}{ }^{-1}$ on the unmanaged and managed watersheds, respectively. Differences were detected for some of the individual time-lag, fuel-size classes, however. Mean 1000-hr fuel loads did not differ between the watersheds (17.9 $\mathrm{Mg} \mathrm{ha}^{-1}$ for the unmanaged watershed, 14.1 $\mathrm{Mg} \mathrm{ha}{ }^{-1}$ for the managed watershed; $\mathrm{p}=0.09$ ), but differences were detected based upon 1000-hr fuel soundness. Mean rotten 1000-hr fuel loads were greater on the unmanaged watershed $\left(16.8 \mathrm{Mg} \mathrm{ha}^{-1}\right)$ than on the managed watershed $\left(10.5 \mathrm{Mg} \mathrm{ha}^{-1}\right)(\mathrm{p}=0.02)$, but the mean for sound 1000 -hr fuel loads did not differ $\left(1.2 \mathrm{Mg} \mathrm{ha}^{-1}\right.$ on the unmanaged watershed, $3.6 \mathrm{Mg} \mathrm{ha}^{-1}$ on the managed watershed; $\mathrm{p}=0.55$ ). Mean 100-hr fuel loads did not differ by watershed (4.3 $\mathrm{Mg} \mathrm{ha}^{-1}$ on the unmanaged watershed, $5.8 \mathrm{Mg} \mathrm{ha}^{-1}$ on the managed watershed; $\mathrm{p}=0.14$ ). Mean $10-\mathrm{hr}$ fuel loads were greater on the managed watershed than on the unmanaged watershed (3.6 $\mathrm{Mg} \mathrm{ha}^{-1}$ for the unmanaged watershed, $5.0 \mathrm{Mg} \mathrm{ha}^{-1}$ for the managed watershed; $\mathrm{p}=0.04$ ) and mean 1-hr fuel loads were greater on the unmanaged watershed than on the managed watershed (0.6 $\mathrm{Mg} \mathrm{ha}{ }^{-1}$ for the unmanaged watershed, $0.2 \mathrm{Mg} \mathrm{ha}^{-1}$ for the managed watershed; $\mathrm{p}<0.01$ ).

\subsection{Forest floor and mineral soil chemistry}

Significant difference determination for chemical properties between the watersheds was similar for the forest floor materials: mean values were higher on the unmanaged watershed for all properties $(\mathrm{p}<0.05)$ except litter $\mathrm{C}(\mathrm{p}=0.13)$ (Tables 3 and 4$)$. Differences in mineral soil chemical properties were not as uniform for the $0-10$ (Table 5) and 10-20 cm (Table 6) soil depths. Mean total P and Ca were significantly greater on the unmanaged watershed at both the $0-10$ 
Table 3

Mean litter (Oi Horizon) chemical property values ( \pm standard error) for the managed and unmanaged watersheds on the Santee Experimental Forest, Cordesville, SC, USA ( $\alpha=0.05)$.

\begin{tabular}{lllll}
\hline $\begin{array}{l}\text { Chemical } \\
\text { Property }\end{array}$ & $\begin{array}{l}\text { Managed } \\
(\mathrm{n}=20)\end{array}$ & $\begin{array}{l}\text { Unmanaged } \\
(\mathrm{n}=16)\end{array}$ & $\begin{array}{l}\text { Test } \\
\text { Statistic }\end{array}$ & p-value \\
\hline $\mathrm{pH}$ & $3.88(0.04)$ & $4.32(0.11)$ & 3.45 & $<0.01$ \\
$\mathrm{P}\left(\mathrm{mg} \mathrm{kg}^{-1}\right)$ & $13.05(0.68)$ & $21.94(1.36)$ & 4.50 & $<0.01$ \\
${\mathrm{Ca}\left(\mathrm{m} \mathrm{kg}^{-1}\right)}_{\mathrm{Mg}\left(\mathrm{mg} \mathrm{kg}^{-1}\right)}$ & $951.50(29.34)$ & $675.00(80.83)$ & 3.93 & $<0.01$ \\
$\mathrm{~K}\left(\mathrm{mg} \mathrm{kg}^{-1}\right)$ & $57.05(5.04)$ & $168.44(12.07)$ & 4.06 & $<0.01$ \\
$\mathrm{~N} \%$ & $0.85(0.04)$ & $1.04(0.03)$ & 3.63 & $<0.01$ \\
$\mathrm{C} \%$ & $46.05(0.31)$ & $46.56(0.35)$ & 1.53 & 0.13 \\
\hline
\end{tabular}

Table 4

Mean duff (Oe + Oa Horizon) soil chemical property values ( \pm standard error) for the managed and unmanaged watersheds on the Santee Experimental Forest, Cordesville, SC, USA ( $\alpha=0.05)$.

\begin{tabular}{lllll}
\hline $\begin{array}{l}\text { Chemical } \\
\text { Property }\end{array}$ & $\begin{array}{l}\text { Managed } \\
(\mathrm{n}=10)\end{array}$ & $\begin{array}{l}\text { Unmanaged } \\
(\mathrm{n}=16)\end{array}$ & $\begin{array}{l}\text { Test } \\
\text { Statistic }\end{array}$ & p-value \\
\hline $\mathrm{pH}$ & $3.88(0.04)$ & $4.18(0.08)$ & -3.12 & $<0.01$ \\
$\mathrm{P}\left(\mathrm{mg} \mathrm{kg}^{-1}\right)$ & $14.80(0.99)$ & $21.44(1.34)$ & -2.85 & $<0.01$ \\
$\mathrm{Ca}\left(\mathrm{mg} \mathrm{kg}^{-1}\right)$ & $411.00(46.30)$ & $849.69(83.40)$ & -3.35 & $<0.01$ \\
$\mathrm{Mg}\left(\mathrm{mg} \mathrm{kg}^{-1}\right)$ & $55.20(4.46)$ & $111.81(10.54)$ & -3.35 & $<0.01$ \\
$\mathrm{~K}\left(\mathrm{mg} \mathrm{kg}^{-1}\right)$ & $43.10(2.94)$ & $84.19(5.31)$ & -3.93 & $<0.01$ \\
$\mathrm{~N} \%$ & $0.93(0.06)$ & $1.32(0.07)$ & -3.03 & $<0.01$ \\
$\mathrm{C} \%$ & $34.14(2.10)$ & $39.34(1.42)$ & -2.13 & 0.03 \\
\hline
\end{tabular}

(both $\mathrm{p}<0.01$ ) and 10-20 cm soil depths (soil P, p $<0.01$; soil Ca, $\mathrm{p}=0.03)$.

\section{Discussion}

4.1. Forest management has altered stand density, species composition, and fuels

This long-term, paired watershed experiment was developed in the 1960s on the Santee Experimental Forest in Cordesville, SC, USA. These watersheds were originally selected for a paired study because their structural and functional attributes were similar. Therefore, this assessment is based upon an assumption of initial similarity across ecosystem components between the watersheds when the paired study was originally established. Additionally, this investigation focused on similar soil series representing only one soil order (Ultisols) present on both watersheds. Since the 1960s, differences in management strategy have resulted in significant differences in species composition, density, and structure between the watersheds. Management activities have decreased total basal area and increased softwood basal area on the managed watershed, while total and hardwood basal area increased in the unmanaged watershed. Forest management practices are often implemented to maintain specific, desired densities and stocking (Waldrop

Table 5

Mean mineral soil chemical property values ( \pm standard error) at the $0-10 \mathrm{~cm}$ soil depth for the managed and unmanaged watersheds on the Santee Experimental Forest, Cordesville, SC, USA $(\alpha=0.05)$.

\begin{tabular}{llllc}
\hline $\begin{array}{l}\text { Chemical } \\
\text { Property }\end{array}$ & $\begin{array}{l}\text { Managed } \\
(\mathrm{n}=20)\end{array}$ & $\begin{array}{l}\text { Unmanaged } \\
(\mathrm{n}=16)\end{array}$ & $\begin{array}{l}\text { Test } \\
\text { Statistic }\end{array}$ & p-value \\
\hline $\mathrm{pH}$ & $4.40(0.03)$ & $4.40(0.09)$ & -0.66 & 0.51 \\
$\mathrm{P}\left(\mathrm{mg} \mathrm{kg}^{-1}\right)$ & $6.85(0.36)$ & $11.75(0.87)$ & 5.19 & $<0.01$ \\
$\mathrm{Ca}\left(\mathrm{m} \mathrm{kg}^{-1}\right)$ & $200.40(23.02)$ & $455.75(78.37)$ & 3.22 & $<0.01$ \\
$\mathrm{Mg}\left(\mathrm{mg} \mathrm{kg}^{-1}\right)$ & $41.80(4.70)$ & $48.38(5.50)$ & 1.05 & 0.29 \\
$\mathrm{~K}\left(\mathrm{mg} \mathrm{kg}^{-1}\right)$ & $27.80(1.81)$ & $32.31(2.36)$ & 1.69 & 0.09 \\
$\mathrm{~N} \%$ & $0.13(0.01)$ & $0.15(0.02)$ & 0.89 & 0.37 \\
$\mathrm{C} \%$ & $2.87(0.23)$ & $2.96(0.34)$ & -0.10 & 0.92 \\
\hline
\end{tabular}

Table 6

Mean mineral soil chemical property values ( \pm standard error) at the 10-20 cm soil depth for the managed and unmanaged watersheds on the Santee Experimental Forest, Cordesville, SC, USA ( $\alpha=0.05)$.

\begin{tabular}{lllll}
\hline $\begin{array}{l}\text { Chemical } \\
\text { Property }\end{array}$ & $\begin{array}{l}\text { Managed } \\
(\mathrm{n}=20)\end{array}$ & $\begin{array}{l}\text { Unmanaged } \\
(\mathrm{n}=16)\end{array}$ & $\begin{array}{l}\text { Test } \\
\text { Statistic }\end{array}$ & p-value \\
\hline $\mathrm{pH}$ & $4.33(0.03)$ & $4.48(0.08)$ & 1.31 & 0.19 \\
$\mathrm{P}\left(\mathrm{mg} \mathrm{kg}^{-1}\right)$ & $3.75(0.20)$ & $7.63(0.83)$ & 4.00 & $<0.01$ \\
$\mathrm{Ca}\left(\mathrm{m} \mathrm{kg}^{-1}\right)$ & $249.40(35.26)$ & $497.94(101.54)$ & 2.23 & 0.03 \\
$\mathrm{Mg}\left(\mathrm{mg} \mathrm{kg}^{-1}\right)$ & $55.50(6.93)$ & $50.56(8.48)$ & -0.40 & 0.69 \\
$\mathrm{~K}\left(\mathrm{mg} \mathrm{kg}^{-1}\right)$ & $23.20(1.45)$ & $24.75(1.55)$ & 0.83 & 0.41 \\
$\mathrm{~N} \%$ & $0.07(0.01)$ & $0.09(0.01)$ & 1.30 & 0.19 \\
$\mathrm{C} \%$ & $1.18(0.14)$ & $1.30(0.21)$ & 0.10 & 0.91 \\
\hline
\end{tabular}

and Goodrick, 2012). It has been shown in similar forests of the southeastern Coastal Plain that a reduction in management activities may lead to increased hardwood cover, often in as little as 10 years from the time that management ceases (Noss, 2018).

The impact of management on stand density and species composition is linked to alterations in fuel arrangement and composition on these watersheds, as well. Mean height of down-and-dead woody debris was $4.6 \mathrm{~cm}$ higher and duff depth was $1.4 \mathrm{~cm}$ greater on the unmanaged watershed. This increase in duff depth was followed by increased duff mass on the unmanaged watershed. This is a significant consideration given more recent research suggesting overstory mortality in long-unburned forests is often impacted by duff disturbance and consumption when burned (Kreye et al., 2014). Feeder roots often permeate and expand in the duff layer in unburned forests. When those roots are damaged by fire, immediate or often delayed mortality may occur (Kreye et al., 2017). While total fuel mass was not significantly different between the watersheds, individual woody fuel components were significantly different, including greater 1-hr and rotten 1000-hr fuels on the unmanaged watershed and greater 10-hr fuels on the managed watershed. Given the damage Hurricane Hugo caused in 1989 on these watersheds and the lack of salvage logging on the unmanaged watershed, the increase in rotten 1000-hr fuel loads is logical. Often 1-hr fuel loads increase immediately post-burn in prescribed fire units due to top-kill of saplings, seedlings, and understory species (Waldrop et al., 2010). This is not a universal truth, however, and fuels may vary quite drastically across a given landscape (Vander Yacht et al., 2019; Loudermilk et al., 2017). The increase in 10-hr fuels on the managed watershed may be a result of decreased stand density and increased exposure of pine canopies to wind and ice. Significant wind and ice storms occurred in this region in 2012, 2013, and 2014 and this may be reflected in these values.

Given the expected increase in wildland fire activity in the southeastern region under the continued influence of climate change (Vose et al., 2018), the shift in these fuel dynamics should not go unnoticed. The presence of fuel loads and the availability of those fuel loads to burn are two separate considerations. Even though a given fuel particle is present in a forest stand, this does not indicate that the fuel particle is available to burn. Size and fuel moisture are two factors that must be considered regarding fuel availability (Drury et al., 2014; Keane, 2013). If a severe wildfire were to occur on the unmanaged watershed during particularly dry conditions, for example, increased smoldering and glowing combustion might occur where duff loads are significant. In that instance, increased smoldering and heating might occur for a longer period of time, leading to increased 1000-hr fuel heating and consumption, creating a potential scenario for increased overstory mortality when compared to a potential wildfire ignition in the managed watershed. If complete duff consumption were to occur, mineral soil would be exposed and any subsequent precipitation might lead to increased erosion, sedimentation, and water temperature. Aquatic habitat might also be affected as a result of these changes (Hahn et al., 2019; Bladon et al., 2014). 
Beyond wildfire hazard considerations, Coastal Plain pine forest coarse woody debris compositions may significantly impact wildlife habitat and health. Owens et al. (2008) found that amphibian and anuran capture rates were greatest in plots where coarse woody debris had not been removed in the Sandhills region of South Carolina, USA. Other species, however, did not respond positively to additions of coarse woody debris and the authors hypothesized that some of the dominant amphibians and snakes found in the study area were adapted to burrowing in sandy soil or finding appropriate habitat in the forest floor. In another study of shrew abundance in the southeastern Coastal Plain, Davis et al. (2010) found that the abundance of 2 shrew species, Blarina carolinensis (Bachman) and Sorex longirostris (Bachman), were influenced by coarse woody debris presence on the landscape. Abundance of both species was least in locations where debris was removed. Abundance of another shrew species, Cryptotis parva (Say), was not impacted by debris loads. Additionally, Horn and Hanula (2008) found that arthropod abundance decreased as a result of short-term coarse woody debris removal in loblolly pine stands in South Carolina. The authors suggested that red-cockaded woodpeckers (Picoides borealis Vieillot) and other bark-foraging birds might be impacted by this potential prey reduction.

\subsection{A soil-forming factor was altered by management}

Differences in litter and duff chemistry were noted between the watersheds for all of the chemical properties assessed, with the exception of litter C. Based upon these results, it would appear that the increase in hardwoods within the unmanaged watershed was related to higher $\mathrm{pH}, \mathrm{Ca}, \mathrm{K}, \mathrm{Mg}, \mathrm{N}$, and $\mathrm{P}$ in the litter and duff. Litter materials in this study were not separated by species and no quantitative analysis of litterfall was conducted to determine species-specific litterfall. Therefore, any interpretation of differences is based upon a generalized, relative species mixture determined by the basal area differences between hardwood and softwood species. Species-specific litter chemistry differences have been noted in studies conducted throughout the world, however (Xue et al., 2019; Alexander and Arthur, 2014; Yanai et al., 2012; Hattenschwiler et al., 2008; Vitousek, 1982). Species-specific N differences that might be related to this study may include values for pine needle litter (0.4\%; Krishna and Mohan, 2017) and red maple (0.8\%; Yanai et al., 2012), for example. Watershed tree species composition has been affected by 50 years of forest management and natural disturbance on these watersheds. Therefore, changes in species dominance have impacted a primary soil forming factor: organisms (Jenny, 1941). This change is most likely reflected not only in the presence of the litter and decomposing understory biomass that changed as a result of intensive management and natural disturbance, but also in the microbial communities dependent upon these materials and patterns of immobilization that might be related to these communities.

Of the forest floor chemical properties that differed between the watersheds, only mineral soil $\mathrm{P}$ and Ca remained significantly different as depth increased beyond the forest floor. It seems likely that these differences are related to the litter chemistry differences previously noted. Speculatively, both sites have similar soil orders and parent materials and different rooting and uptake patterns of differing species may have influenced cycling of these two bases. Differences did exist at both depths (0-10 and 10-20 cm) for both P and Ca. Phosphorus levels for the managed watershed soils were approximately $58 \%$ and $49 \%$ of the P levels for the unmanaged watershed soils at the $0-10$ and 10-20 cm depths, respectively. Calcium levels for the managed watershed soils were approximately $44 \%$ and $50 \%$ of the unmanaged watershed soils at the $0-10$ and $10-20 \mathrm{~cm}$ depths, respectively. Phosphorus levels for both soils at both depths might suggest a potential $\mathrm{P}$ limitation for vegetative growth $(<0.005 \%)$. The $\mathrm{P}$ and $\mathrm{Ca}$ mineral soil results did not agree with McKee (1982) who found significant increases in both mineral soil $\mathrm{P}$ and $\mathrm{Ca}$ as a result of burning at the
0-5 cm soil depth in Alabama and 0-8 cm soil depth in South Carolina. Godwin et al. (2017) also found non-significant increases in both Ca and $\mathrm{P}$ at the $0-10 \mathrm{~cm}$ soil depth in Florida. In both of these studies, the authors documented similar shifts in relative overstory species composition between burned and unburned locations (i.e. increased hardwood presence in unburned locations). However, the specific hardwood species present between these locations likely differed with those found at the Santee watersheds. Additionally, in McKee (1982) and Godwin et al. (2017), soils were sampled at different post-fire times than the Santee watersheds. For example, McKee (1982) sampled his Alabama location 4 months post-fire. On the Santee watersheds, soil sampling was conducted 2 years after the last prescribed burn. Any potential pulses that might be expected within the first year after fire (Boerner, 1982; Wells et al., 1979) were most likely mitigated 2 years post-fire on the Santee watersheds.

When comparing the Santee watershed results to those of other studies, the inherent variability and complexity of soil responses can also not be understated. For example, the lack of significant differences for $\mathrm{Mg}$ at the $0-10 \mathrm{~cm}$ depth between the Santee watersheds did not agree with either Godwin et al. (2017) $(0-10 \mathrm{~cm}$ depth, fire increased $\mathrm{Mg}$ ) or McKee (1982) (0-8 cm depth Alabama, biennial dormant fire decreased Mg; 0-5 cm depth South Carolina, annual dormant fire increased Mg). Similar to Godwin et al. (2017) and McKee (1982), nonsignificant differences in $\mathrm{K}$ were observed on the Santee watersheds at both depths. McKee (1982) documented changes in soil pH as a result of annual growing season burns in South Carolina at the $0-5 \mathrm{~cm}$ soil depth, but this was not reflected in the Santee watershed results or those shared by Godwin et al. (2017).

The non-significant changes in mineral soil $\mathrm{N}$ found on the watersheds did agree with similar results stated by other researchers in Coastal Plain Ultisols, regardless of fire frequency or sampling time post-burn (Godwin et al. 2017, Boyer and Miller, 1994; Binkley et al. 1992; McKee, 1982). In a similar study of long-term prescribed fire use in sandy surface soils of the southeastern Coastal Plain (Entisols and Spodosols), Coates et al. (2018) also noted that prescribed fire alone did not drastically impact mineral soil C or $\mathrm{N}$ at the $0-10$ or $10-20 \mathrm{~cm}$ soil depths sampled one year post-fire when compared to unburned soils. The results from these studies contrast the $\mathrm{C}$ and $\mathrm{N}$ assertions made by Carter and Foster (2004) and Pellegrini et al. (2017). In their work, Carter and Foster (2004) cautioned that long-term active management, including prescribed fire, might limit southern pine forest productivity through reductions in mineral soil C and N. Pellegrini et al. (2017), in a study of 48 sites globally, noted that increased wildland fire frequency might reduce mineral soil $\mathrm{C}$ and $\mathrm{N}$. In their results, Pellegrini et al. (2017) did note that prescribed fires in needleleaf forests subjected to prescribed burning might be the exception to their findings. On the Santee Experimental Forest, litter $\mathrm{C}$ and both litter and duff $\mathrm{N}$ were significantly less in the managed watershed, but those results were not present at either mineral soil depth. As noted earlier, investigations of prescribed fire and harvesting impacts on soil properties are influenced by the time since the last treatment was implemented. This study provided a unique opportunity to explore these dynamics 2 years since the last prescribed burn was conducted, therefore the potential direct, immediate impacts of the last prescribed burn should have been mediated.

\subsection{Management implications}

Throughout the southeastern Coastal Plain and around the globe, silvicultural manipulations similar to those implemented on the Santee Experimental Forest watersheds have been and will continue to be applied. These silvicultural activities are used to fulfill numerous management objectives, including but not limited to the development or enhancement of wildlife habitat, wildfire hazard reduction, undesired vegetation control, and provision of ecosystem services, such as water quality (Waldrop and Goodrick, 2012). Evaluations of long-term management regimes are often lacking, particularly ones that include 
prescribed fire and analyses of soil properties. In this regard, this study provided a beneficial assessment of potential changes in soil chemical properties in response to long-term management. Additionally, many ecosystems are impacted by hurricanes and other natural disturbances and this study location provided valuable insight regarding potential, long-term ecosystem responses to such events.

This study was, however, limited in its scope. It is only one evaluation of one management regime in one location within the southeastern Coastal Plain, USA. Soils were confined to one predominant soil order, Ultisols, which is not representative of every soil within these watersheds, the expansive Coastal Plain region, nor other regions globally. Ultisols do, however, account for approximately $8-9 \%$ of Earth's ice-free land surface, supporting approximately $18 \%$ of the world's population (Binkley and Fisher, 2013). Therefore, the emphasis on Ultisols is novel and merited. The number of samples was also limited to 16 and 20 in the unmanaged and managed watersheds, respectively. Additional sampling on these watersheds may have accounted for greater potential variability between the watersheds. In light of these limitations, it should be stated that these results must be compared to those of other studies within the appropriate context.

It should also be noted that a companion study was conducted on these watersheds in 2015 at the same exact sampling locations to determine differences in potential organic matter export from collected litter and duff materials (Majidzadeh et al., 2019). Results from this study suggested that dissolved organic carbon (DOC), total dissolved nitrogen (TDN), and ammonium $\left(\mathrm{NH}_{4}{ }^{+}-\mathrm{N}\right)$ were higher in water extracts originating from the unmanaged watershed litter and duff materials than the managed watershed litter and duff materials ( $\mathrm{p}<0.01$ ). In the field, water samples originating in these watersheds were also collected in 2015 (Majidzadeh et al., 2019). Dissolved organic carbon and TDN were higher in the unmanaged watershed samples for most of the sampling period for these analyses and these results were correlated with forest floor thickness in the unmanaged watershed. During most of the year, haloacetonitrile and trihalomethane, two known disinfection by-product (DBP) precursors that may be related to increased incidence of bladder cancer, rectal cancer, and negative birth outcomes in humans (Plewa et al., 2002; Zeng et al., 2016), were also lower in the managed watershed. These results led the authors to suggest that long-term forest management might best promote long-term water quality and human health. In a recent synthesis study of these watersheds, Amatya and Trettin (2019) concluded that active management had no significant impact on streamflow.

In total, these results suggested that natural disturbance and long-term management practices have developed two unique and separate forested ecosystems within the southeastern Coastal Plain that contained their own unique properties. While most vegetative species were present in both watersheds, their relative presence differed. Therefore, other ecosystem properties may have been altered, such as soil chemistry, as management influenced a primary soil-forming factor: organisms. Both watersheds, as a result of active and inactive management, represented unique ecosystems. In that regard, both watersheds reflected viable management strategies that might be used to promote different ecosystem attributes for potentially different landowner objectives. The techniques practiced on the managed watershed closely aligned with those that might be used to achieve and maintain a fire-adapted community and conditions suited for specific wildlife species, for example. Alternatively, parcels might be managed similarly to the unmanaged watershed to promote a different species composition and habitat conditions that favor other wildlife species. Depending upon the attribute of greatest interest or potential management constraints, a landowner or forest manager might informatively choose one management intensity over another.

\section{Conclusions}

Results from this paired watershed study suggested that natural disturbance and long-term forest management have altered vegetative species composition, fuel loads, and soil chemical properties in the southeastern Coastal Plain, USA. Since the early 1960s, no active management has been conducted on one watershed and a combination of salvage harvesting, thinning, mastication, and prescribed fire has been used on the other watershed. The unmanaged watershed contained greater total tree basal area, greater hardwood basal area, less softwood basal area, greater 1-hr fuels, less 10-hr fuels, and greater 1000-hr rotten fuels than did the managed watershed. Litter and duff $\mathrm{pH}, \mathrm{C}$ (duff-only), $\mathrm{Ca}, \mathrm{K}, \mathrm{Mg}, \mathrm{N}$, and $\mathrm{P}$ were significantly greater on the unmanaged watershed and $\mathrm{Ca}$ and $\mathrm{P}$ were greater in the unmanaged watershed Ultisols at the $0-10$ and $10-20 \mathrm{~cm}$ soil depths. Differences in soil properties between the watersheds were most likely related to an alteration in organisms as a primary soil-forming factor. A recent water quality study conducted at these same locations suggested that a host of water quality variables were enhanced on the managed watershed. Collectively, results from these watersheds suggested that the longterm, active forest management regime utilized on the managed watershed created a unique ecosystem with distinct attributes. Overall, this study highlighted some of the potential effects that intensive silvicultural options offer to landowners, having different objectives and potential constraints, and how one management regime might be selected over another to target specific species compositions, wildlife habitat components, and ecosystem services.

\section{CRediT authorship contribution statement}

T. Adam Coates: Conceptualization, Methodology, Formal analysis, Writing - original draft, Writing - review \& editing, Visualization. Andrew Johnson: Formal analysis, Writing - original draft, Writing review \& editing. W. Michael Aust: Methodology, Formal analysis, Writing - review \& editing. Donald L. Hagan: Conceptualization, Writing - review \& editing. Alex T. Chow: Conceptualization, Writing review \& editing. Carl Trettin: Conceptualization, Writing - review \& editing.

\section{Declaration of Competing Interest}

The authors declare that they have no known competing financial interests or personal relationships that could have appeared to influence the work reported in this paper.

\section{Acknowledgements}

None of this work would have been possible without the efforts of the USDA Forest Service Southern Research Station Center for Forested Wetlands Research. The authors additionally wish to acknowledge Mary-Frances Rogers Wolf, Jennie Untener, Brian Williams, David Miller, Rob O'Neal, Ryan Marsh, Caleb Keen, Chris Dukes, and George Hahn for their assistance collecting forest floor samples from the watersheds and preparing the samples for analysis.

\section{References}

Abatzoglou, J.T., Williams, A.P., 2016. Impact of anthropogenic climate change on wildfire across western US forests. Proc. Natl. Acad. Sci. USA 113 (42), 11770-11775. https://doi.org/10.1073/pnas.160717113.

Alexander, H., Arthur, M., 2014. Increasing red maple leaf litter alters decomposition rates and nitrogen cycling in historically oak-dominated forests of the eastern U.S Ecosystems 17, 1371-1383. https://doi.org/10.1007/s10021-014-9802-4.

Alcaniz, M., Outeiro, L., Francos, M., Ubeda, X., 2018. Effects of prescribed fires on soil properties: a review. Sci. Total Environ. 613-614 (1), 944-957. https://doi.org/10. 1016/j.scitotenv.2017.09.144.

Amatya, D.M., Miwa, M., Harrison, C.A., Trettin, C.C., Sun, G., 2006. Hydrology and water quality of two first order forested watershed in coastal South Carolina. ASABE Paper Number 062182. American Society of Agricultural and Biological Engineers, St. Joseph, MI, USA. https://www.srs.fs.usda.gov/pubs/ja/ja_amatya022.pdf.

Amatya, D.M., Trettin, C.C., 2007. Development of watershed hydrologic research at Santee Experimental Forest, coastal South Carolina. In: Furniss, M.J., Clifton, C.F., Ronnenberg, K.L. (eds.), Advancing the Fundamental Sciences, Proceedings of the 
Forest Service National Earth Sciences Conference, San Diego, CA, USA, 18-22 October 2004 Volume 1. USDA Forest Service Pacific Northwest Research Station General Technical Report PNW-GTR-689, Portland, OR, USA, pp. 180-190. https:// www.fs.fed.us/pnw/pubs/pnw_gtr689.pdf.

Amatya, D.M., Trettin, C.C., 2019. Long-term ecohydrologic monitoring: a case study from the Santee Experimental Forest, South Carolina. J. South Carolina Water Resour. 6 (1), 46-55.

Anderson, H.E., 1982. Aids to determining fuel models for estimating fire behavior. USDA Forest Service Intermountain Forest and Range Experiment Station General Technical Report GTR-INT-122, Ogden, UT, USA, 22 p. https://www.fs.fed.us/rm/pubs_int/int_ gtr122.pdf.

Aust, W.M., Bolding, M.C., Barrett, S.M., 2019. Silviculture in forested wetlands: summary of current forest operations, potential effects, and long-term experiments. Wetlands. https://doi.org/10.1007/s131470019-01191-6.

Binkley, D., Fisher, R.F., 2013. Ecology and Management of Forest Soils, fourth ed. JohnWiley \& Sons, Chichester, West Sussex, UK, pp. 8-20.

Binkley, D., Richter, D.D., David, M., Caldwell, B., 1992. Soil chemistry in a loblolly/ longleaf pine forest with interval burning. Ecol. Appl. 2, 157-164.

Bladon, K.D., Emelo, M.B., Silins, U., Stone, M., 2014. Wildfire and the future of water supply. Environ. Sci. Technol. 48, 8936-8943.

Boerner, R.E.J., 1982. Fire and nutrient cycling in temperate ecosystems. Bioscience 32 (3), 187-192.

Boss, C., Fredeen, K., 2004. Concepts, instrumentation, and techniques in inductively coupled plasma optical emissionspectrometry, third ed. Perkin Elmer Life and Analytical Sciences, Sheldon, CT, USA.

Boyer, W., Miller, J., 1994. Effect of burning and brush treatments on nutrient and soil physical properties in young longleaf pine stands. For. Ecol. Manage. 70, 311-318.

Brown, J.K., 1974. Handbook for inventorying downed woody material. Gen. Tech. Rep. INT-16. Ogden, UT: U.S. Department of Agriculture Forest Service, Intermountain Forest and Range Experiment Station. 24 p.

Carter, M.C., Foster, C.D., 2004. Prescribed burning and productivity in southern pine forests: a review. For. Ecol. Manage. 191, 93-109. https://doi.10.1016/j.foreco. 2003.11.006.

Coates, T.A., 2006. Response of forest soil resources to fuel reduction in the southeastern Piedmont and southern Appalachian Mountains. M.S. Thesis, Clemson University, Clemson, SC, USA. 104 p.

Coates, T.A., Hagan, D.L., Aust, W.M., Johnson, A., Keen, J.C., Chow, A.T., Dozier, J.H., 2018. Mineral soil chemical properties as influenced by long-term use of prescribed fire with differing frequencies in a southeastern Coastal Plain pine forest. Forests 9 , 739. https://doi.org/10.3390/f9120739.

Coates, T.A., Waldrop, T.A., Mohr, H.H., Hutchinson, T.F., 2019. The Appalachian Mountain fuel photo series: a resource for fire managers and practitioners. USDA Forest Service Southern Research Station, General Technical Report GTR-SRS-241, Asheville, NC, USA. 180 p. https://www.srs.fs. usda.gov/pubs/gtr/gtr_srs241.pdf.

Collins, M., Knutti, R., 2013. Chapter 12-Long-term climate change: projections, commitments, and irreversibility. In: Stocker, T.F., Qin, D., Plattner, G., Tignor, M., Allen, S.K., Boschung, J., Nauels, A., Xia, Y., Bex, V., Midgley, M.P. (eds.), Climate Change 2013: The Physical Science Basis. Contribution of Working Group I to the Fifth Assessment Report of the Intergovernmental Panel on Climate Change. Cambridge University Press, Cambridge, UK and New York, NY, USA. 1535 p. doi. 10.1017/ CBO9781107415324.

Davis, J.C., Castleberry, S.B., Kilgo, 2010. Influence of coarse woody debris on the soricid community in southeastern Coastal Plain pine stands. J. Mammal. 91(4), 993-999.

Dai, Z., Trettin, C.C., Amatya, D.M., 2013. Effects of climate variability on forest hydrology and carbon sequestration on the Santee Experimental Forest in coastal South Carolina. USDA Forest Service Southern Research Station GTR-SRS-172, Asheville, NC, USA. https://www.srs.fs.fed.us/pubs/gtr/gtr_srs172.pdf.

Drury, S.A., Larkin, N.S., Strand, T.T., Huang, S., Strenfel, S.J., Banwell, E.M., O’Brien, T.E., Raffuse, S.M., 2014. Intercomparison of fire size, fuel loading, fuel consumption, and smoke emissions estimates on the 2006 Tripod Fire, Washington, USA. Fire Ecol. $10,56-83$.

Fairchilds, L., Trettin, C., 2006. History and legacy of fire effects in the South Carolina Piedmont and Coastal Regions. General Technical Report SRS-98, USDA Forest Service Southern Research Station: Asheville, NC, USA.

Flannigan, M., Cantin, A.S., de Groot, W.J., Wotton, M., Newbery, A., Gowman, L.M., 2013. Global wildland fire season severity in the $21^{\text {st }}$ century. For. Ecol. Manage. 294, 54-61. https://doi.org/10.1016/j.foreco.2012.10.022.

Fox, T.R., Jokela, E.J., Allen, H.L., 2007. The development of pine plantation silviculture in the southern United States. J. Forest. 105 (7), 337-347.

Gilliam, F.S., Platt, W.J., 1999. Effects of long-term fire exclusion on tree species composition and stand structure in an old-growth Pinus palustris (longleaf pine) forest. Plant Ecol. 140 (1), 15-26.

Glitzenstein, J.S., Streng, D.R., Wade, D.D., 1993. Fire frequency effects on longleaf pine (Pinus palustris) vegetation in South Carolina and Northeast Florida, USA. Natural Areas J. 23, 22-27.

Godwin, D., Kobziar, L., Robertson, K., 2017. Effects of fire frequency and soil temperature on soil $\mathrm{CO}_{2}$ efflux rates in old-field pine-grassland forests. Forests 8, 274.

Hahn, G.E., Coates, T.A., Latham, R.E., Majidzadeh, H., 2019. Prescribed fire effects on water quality and freshwater ecosystems in moist-temperate eastern North America. Natural Areas J. 39, 46-57. https://doi.org/10.3375/043.039.0104.

Harder, S.V., Amatya, D.M., Callahan, T.J., Trettin, C.C., 2006. Modeling the monthly water balance of a first order coastal forested watershed. In: Williams, T. (ed.), Hydrology and Management of Forested Wetlands: Proceedings of the International Conference. American Society of Agricultural and Biological Engineers: St. Joseph, MI, USA. pp. 218-230. https://www.srs.fs.usda.gov/pubs/ja/ja_amatya016.pdf.

Hattenschwiler, S., Aeschlimann, B., Couteaux, M., Roy, J., Bonal, 2008. High variation in foliage and leaf litter chemistry among 45 tree species of a neotropical rainforest community. New Phytol. 179, 165-175. doi: 10.1111/j.1469-8137.2008.02438.x.

Hiers, J.K., O’Brien, J.J., Mitchell, R.J., Grego, J.M., Loudermilk, E.L., 2009. The wildland fuel cell concept: an approach to characterize fine-scale variation in fuels and fire in frequently burned longleaf pine forests. Int. J. Wildland Fire 18, 315-325.

Hook, D.D., Buford, M.A., Williams, T.M., 1991. Impact of Hurricane Hugo on the South Carolina coastal plain pine forest. J. Coastal Res. 7, 291-300. https://www.jstor.org/ stable/25735422.

Horn, S., Hanula, J.L., 2008. Relationship of coarse woody debris to arthropod availability for red-cockaded woodpeckers and other bark-foraging birds on loblolly pine boles. J. Entomol. Sci. 43 (2), 153-168.

Hume, A., Chen, H.Y.H., Taylor, A.R., Kayahara, G.J., Man, R., 2016. Soil C:N: P dynamics during secondary succession following fire in the boreal forest of central Canada. For. Ecol. Manage. 369, 1-9. https://doi.org/10.1016/j.foreco.2016.03.033.

Jayakaran, A.D., Williams, T.M., Ssegane, H., Amatya, D.M., Song, B., Trettin, C.C., 2014. Hurricane impacts on a pair of coastal forested watersheds: implications of selective hurricane damage to forest structure and streamflow dynamics. Hydrol. Earth Syst. Sci. 18, 1151-1164. https://doi.org/10.5194/HESS-18-1151-2014.

Jenny, H., 1941. Factors of soil formation: a system of quantitative pedology. Dover Earth Sci. 281.

Johnson, D.W., Curtis, P.S., 2001. Effects of forest management on soil C and N: meta analysis. For. Ecol. Manage. 140, 227-238.

Keane, R.E., 2013. Describing wildland surface fuel loading for fire management: a review of approaches, methods, and systems. Int. J. Wildland Fire 22, 51-62. https://doi. org/10.1071/WF11139.

Keenan, R.J., Reams, G.A., Achard, F., de Freitas, J.V., Grainger, A., Lindquist, E., 2015. Dynamics of global forest area: results from the FAO Global Forest Resources Assessment 2015. For. Ecol. Manage. 352, 9-20.

Kreye, J.K., Varner, J.M., Dugaw, C.J., 2014. Spatial and temporal variability of forest floor duff characteristics in long-unburned Pinus palustris forests. Can. J. For. Res. 44 (12), 1477-1486.

Kreye, J.K., Varner, J.M., Dugaw, C., Engber, E., Quinn-Davidson, L., 2017. Patterns of duff ignition and smoldering beneath old Pinus palustris: influence of tree proximity, moisture content, and ignition vectors. Forest Sci. 16, 165-172.

Krishna, M.P., Mohan, M., 2017. Litter decomposition in forest ecosystems: a review. Energy, Ecol. Environ. 2 (4), 236-249.

Li, Y., Yang, F., Ou, Y., Zhang, D., Liu, J., Chu, G., Zhang, Y., Otieno, D., Zhou, G., 2013. Changes in forest soil properties in different successional stages in lower tropical China. PLoS ONE. https://doi.org/10.1371/journal.pone.0081359.

Loudermilk, E., Hiers, J., O'Brien, J., 2017. The role of fuels for understanding fire behavior and fire effects. In: Kirkman, L., Jack, S. (eds.), Ecological Restoration and Management of Longleaf Pine Forests. CRC Press: Boca Raton, FL, USA, pp. 107-122.

Lutes, D.C., Keane, R.E., 2006. Fuel load (FL) sampling method. In: Lutes, D.C., Keane, R. E., Caratti, J.F., Key, C.H., Benson, N.C., Sutherland, S., Gangi, L.J. (eds.), FIREMON: fire effects monitoring and inventory system. USDA Forest Service Rocky Mountain Research Station General Technical Report RMRS-GTR-164-CD. Fort Collins, CO, USA, pp. FL-1-21. https://www.fs.fed.us/rm/pubs/rmrs_gtr164/rmrs_gtr164_06_fuel load.pdf.

Lynham, T.J., Wickware, G.M., Mason, J.A., 1998. Soil chemical changes and plant succession following experimental burning in immature jack pine. Can. J. Soil Sci. 78, 93-104. https://www.nrcresearchpress.com/doi/pdf/10.4141/S97-031.

Majidzadeh, H., Chen, H., Coates, T.A., Tsai, K.P., Olivares, C.I., Trettin, C., Uzun, H., Karanfil, T., Chow, A.T., 2019. Long-term watershed management is an effective strategy to reduce organic matter export and disinfection by-product precursors in source water. Int. J. Wildland Fire 28 (804-813), 822. https://doi.org/10.1071/ WF18174_CO.

Maser, C., Anderson, R.G., Cromack, K., Williams, J.T., Cummins, K.W., 1979. Dead and down woody material. In: Thomas, J. (ed.), Wildlife habitats in managed forests, the Blue Mountains of Oregon and Washington. USDA Forest Service Washington Office Agricultural Handbook 553, Washington, DC, USA.

McKee, W.H., 1982. Changes in soil fertility following prescribed burning on coastal plain pine sites. USDA Forest Service Southeastern Forest Experiment Station, Asheville, NC, USA.

McLean, E., 1982. Soil pH and lime requirement. In: Page, A. (ed.), Methods of Soil Analysis, part 2. Agronomy Monographs 9, 2nd ed. American Society of Agronomy and Soil Science Society of America, Madison, WI, USA, pp. 199-223.

Mehlich, A., 1984. Mehlich 3 soil test extractant: a modification of Mehlich 2 extractant. Commun. Soil Sci. Plan. 15, 1409-1416. https://doi.org/10.1080/ 00103628409367568.

Melvin, M., 2018. 2018 National Prescribed Fire Use Report.

Mitchell, R.J., Duncan, S.L., 2009. Range of variability in Southern Coastal Plain forests: its historical, contemporary, and future role in sustaining biodiversity. Ecol. Soc. 14 (1), 17. http://www.ecologyandsociety.org/vol14/iss1/art17/.

Nelson, D., Sommers, L., 1996. Total carbon, organic carbon, and organic matter. In: Bartels, J. (ed.), Methods of Soil Analysis: Part 3 Chemical Methods. 3rd ed., ASA and SSSA Book Series 5. American Society of Agronomy and Soil Science Society of America, Madison, WI, USA, 1996, pp. 961-1010.

Noss, R.F., 2018. Fire Ecology of Florida and the Southeastern Coastal Plain. University Press of Florida, Gainesville, FL, USA.

Oliver, C.D., Larson, B.C., 1996. Forest Stand Dynamics. Update edition. Wiley and Sons, Inc.

Owens, A.K., Moseley, K.R., McCay, T.S., Castleberry, S.B., Kilgo, J.C., Ford, W.M., 2008 Amphibian and reptile community response to coarse woody debris manipulations in upland loblolly pine (Pinus taeda) forests. For. Ecol. Manage. 256, 2078-2083.

Page-Dumroese, D., Jurgensen, M., Neary, D., Curran, M., Trettin, C., 2010. Soil quality is fundamental to ensuring healthy forests. In: Pye, J.M., Rauscher, H.M., Sands, Y., Lee, 
D.C., Beatty, J.S. (eds.), Advances in Threat Assessment and Their Application to Forest and Rangeland Management. USDA Forest Service Pacific Northwest Research Station General Technical Report PNW-GTR-802. Portland, OR, USA, pp. 27-36. https://www.fs.fed.us/pnw/pubs/pnw_gtr802/pnw_gtr802a.pdf.

Pellegrini, A., Ahlstrom, A., Hobbie, S., Reich, P., Nieradzik, L., Staver, A., Scharenbroch, B., Jumpponen, A., Anderegg, W., Randerson, J., Jackson, R.B., 2017. Fire frequency drives decadal changes in soil carbon and nitrogen in ecosystem productivity. Nature 553, 194-198.

Plewa, M.J., Kargalioglu, Y., Vankerk, D., Minear, R.A., Wagner, E.D., 2002. Mammalian cell cytotoxicity and genotoxicity analysis of drinking water disinfection by-products. Environ. Mol. Mutagen. 40, 134-142. https://doi.org/10.1002/EM.10092.

Schwilk, D.W., Keeley, J.E., Knapp, E.E., McIver, J., Bailey, J.D., Fettig, C.J., Fiedler, C.E., Harrod, R.J., Moghaddas, J.J., Outcalt, K.W., Skinner, C.N., Stephens, S.L., Waldrop, T.A., Yaussy, D.A., Youngblood, A., 2009. The national Fire and Fire Surrogate study: effects of fuel reduction methods on forest vegetation structure and fuels. Ecol. Appl. 19 (2), 285-304. https://doi.org/10.1890/07-1747.1.

Stottlemyer, A.D., 2004. Fuel characterization of the Chauga Ridges regions of the Southern Appalachian Mountains. Clemson, SC: Clemson University. M.S. thesis. $87 \mathrm{p}$.

Tiribelli, F., Kitzberger, T., Morales, J.M., 2019. Changes in vegetation structure and fuel characteristics along post-fire succession promote alternative stable states and positive post fire-vegetation feedbacks. J. Veg. Sci. 29 (2), 147-156. https://doi.org/10. 1111/jvs.12620.

Uyehara, I., Pacala, S.W., 2018. The role of succession in the evolution of flammability. Theor. Ecol. 11 (3), 291-303. https://10.1007/s12080-018-0366-3.

Vander Yacht, A.L., Keyser, P.D., Kwit, C., Stambaugh, M.C., Clatterbuck, W.K., Simon, D.M., 2019. Fuel dynamics during oak woodland and savanna restoration in the MidSouth USA. Int. J. Wildland Fire 28 (1), 70-84. https://doi.org/10.1071/WF18048.

Vitousek, P., 1982. Nutrient cycling and nutrient use efficiency. Am. Nat. 119 (4), 553-572.

Waldrop, T.A., Goodrick, S.L., 2012. Introduction to prescribed fires in southern ecosystems. Science Update SRS-054, USDA Forest Service Southern Research Station,
Asheville, NC, USA. $80 \mathrm{p}$

Waldrop, T.A., Phillips, R.J., Simon, D.A., 2010. Fuels and predicted fire behavior in the southern Appalachian Mountains after fire and fire surrogate treatments. Forest Sci. 56 (1), 32-45.

Vose, J.M., Peterson, D.L., Domke, G.M., Fettig, C.J., Joyce, L.A., Keane, R.E., Luce, C.H., Prestemon, J.P., Band, L.E., Clark, J.S., Cooley, N.E., D'Amato, A., Halofsky, J.E., 2018. Forests. In: Reidmiller, D.R., Avery, C.W., Easterling, D.R., Kunkel, K.E., Lewis, K.L.M., Maycock, T.K., Stewart, B.C. (Eds.), Impacts, Risks, and Adaptation in the United States: Fourth National Climate Assessment. Volume II. U.S. Global Change Research Program, Washington, DC, USA, pp. 232-267. https://doi.org/10.7930/ NCA4.2018.CH6.

Waldrop, T.A., Hagan, D.L., Simon, D.M., 2016. Repeated application of fuel reduction treatments in the southern Appalachian Mountains: implications for achieving management goals. Fire Ecol. 12 (2), 28-47. https://doi.10.4996/fireecology. 1202028.

Wells, C.G., Campbell, R.E., DeBano, L.F., Lewis, C.E., Frederickson, R.L., Franklin, E.C., Froelich, R.C., Dunn, P.H., 1979. Effects of fire on soil: a state-of-the-knowledge review. Gen. Tech. Rep. WO- 7. Washington, DC: U.S. Department of Agriculture, Forest Service. 34 p.

Williams, J., 2013. Exploring the onset of high-impact mega-fires through a forest land management prism. For. Ecol. Manage. 294, 4-10. https://doi.org/10.1016/j.foreco. 2012.06.030.

Xue, F., Zhao, M., Wang, Y., Kang, M., Xing, K., Wang, G., Shi, J., Chen, C., Jiang, Y., 2019. Base cation concentrations in forest litter and topsoil have different responses to climate and tree species along elevational gradients. J. Mountain Sci. 16, 30-42.

Yanai, R.D., Arthur, M.A., Acker, M., Levine, C.R., Park, B.B., 2012. Variation in mass and nutrient concentration of leaf litter across years and sites in a northern hardwood forest. Can. J. For. Res. 42 (8), 1598-1610.

Zeng, T., Plewa, M.J., Mitch, W.A., 2016. N-nitrosamines and halogenated disinfection by-products in U.S.: full advanced treatment trains for potable reuse. Water Res. 101, 176-186. https://doi.org/10.1016/j.watres.2016.03.062. 